\title{
Microbial Colonization of Retorted Shale in Field and Laboratory Studies
}
J. E. Rogers
V. M. McNair
S. W. Li
T. R. Garland
R. E. Wildung

August 1982

Prepared for the U.S. Department of Energy under Contract DE-AC06-76RLO 1830

Pacific Northwest Laboratory

Operated for the U.S. Department of Energy by Battelle Memorial Institute 


\title{
DISCLAIMER
}

This report was prepared as an account of work sponsored by an agency of the United States Government. Neither the United States Government nor any agency thereof, nor any of their employees, makes any warranty, express or implied, or assumes any legal liability or responsibility for the accuracy, completeness, or usefulness of any information, apparatus, product, or process disclosed, or represents that its use would not infringe privately owned rights. Reference herein to any specific commercial product, process, or service by trade name, trademark, manufacturer, or otherwise, does not necessarily constitute or imply its endorsement, recommendation, or favoring by the United States Government or any agency thereof. The views and opinions of authors expressed herein do not necessarily state or reflect those of the United States Government or any agency thereof.

\author{
PACIFIC NORTHWEST I.ABORATORY \\ operated by \\ BATTELLE \\ for the \\ UNITED STATES DEPARTMENT OF ENERGY \\ under Contract DE-AC06-76RLO 1830
}

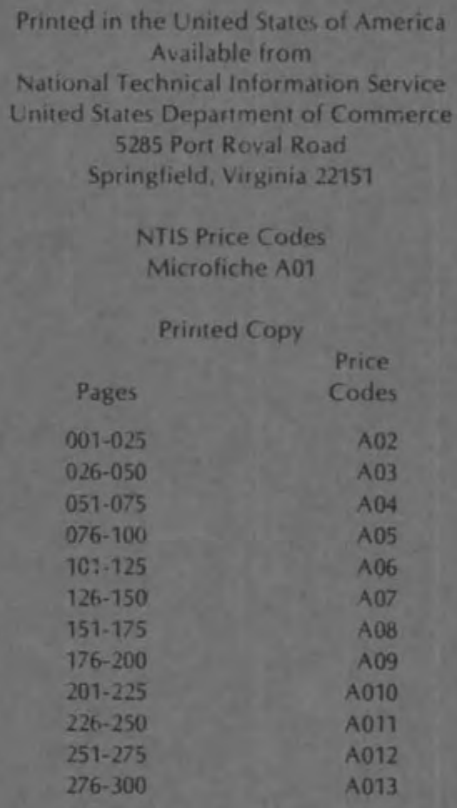


MICROBIAL COLONIZATION OF

RETORTED SHALE IN

FIELD AND LABORATORY STUDIES

\author{
J.E. Rogers \\ V.M. McNair \\ S.W. Li \\ T.R. Garland \\ R.E. Wildung
}

August 1982

Prepared for

the U.S. Department of Energy

under Contract DE-AC06-76RLO 1830

Pacific Northwest Laboratory

Richland, Washington 99352 
SUMMARY

The microbial colonization of retorted shale was measured in field lysimeters and laboratory with retorted shale obtained from an above-ground retort operating in the direct heating mode. In field lysimeter studies, total aerobic heterotrophic bacterial colony forming units (cfu), as measured by a selective plating medium in surface horizons of retorted shale and adjacent soils, were similar $\left(3.3 \times 10^{6}\right.$ and $2.7 \times 10^{6}$ bacterial cfu/g dry weight) two months after disposal. However, unlike the soil that exhibited a diverse community, the retorted shale was dominated by a single Micrococcus species that composed $30 \%$ of the total bacterial community. After one and two years, the total aerobic heterotrophic bacterial cfu in the retorted shale and soil were again similar; however, no bacterium dominated either community. A core sample from the field lysimeter indicated microbial colonization to a depth of $150 \mathrm{~cm}$ after one year. An increased ratio of anaerobic to aerobic heterotrophic bacterial cfu in the deepest sample $(120-150 \mathrm{~cm})$ implied the development of anaerobic conditions. In the laboratory, aerobic heterotrophic bacteria were shown capable of using, as the sole source of carbon, retorted shale in liquid cultures. Of the added nutritional amendments, $\mathrm{PO}_{4}^{-3}, \mathrm{NO}_{3}^{-}$and $\mathrm{SO}_{4}^{-2}$, only phosphate markedly altered the colonization of retorted shale in liquid culture; shortening the lag phase of colonization from less than three to seven weeks to less than one week and leading to a greater aerobic heterotrophic population over the incubation interval. The addition of phosphate also led to a aerobic heterotrophic bacterial community composed entirely of Micrococcus species. 


\section{INTRODUCTION}

$0 i 1$ shale is universally considered a viable source of domestic crude $0 i 1$ and numerous technologies have or are being developed to convert oil shale to a usable crude oil. A significant portion of the oil shale will be processed by above-ground retorting methods which will produce retorted shale as the major waste (Routson et al. 1979). Retorted shale, which is composed primarily of the residual inorganic fraction, is produced from oil shale at high temperatures $\left(400-600^{\circ} \mathrm{C}\right.$ ) during the retorting process (Development Engineering 1979). During retorting, organic constituents are converted to compounds that are stable to the retorting temperature and are either removed, as in shale oil, or left as residual organic components of the waste retorted shale (up to $5 \%$ organic carbon). Changes may also occur in the mineral fraction.

A large portion of the retorted shale will be disposed to the surface at designated disposal sites. Accordingly, the solubility and mobility of the organic residues and potential inorganic pollutants (e.g., salts and trace metals) in retorted shale needs to be defined in order to assess possible movement to ground and surface waters and potential effects on revegetation of disposal sites.

The mobility of organic and inorganic residues in retorted shale after disposal will initially depend on retorting conditions as well as a number of physical and chemical processes. However, with environmental aging, microbial colonization of disposed retorted shale may have a major influence on certain of these processes. The effects of microorganisms will be dependent, in part, on their ability to use the organic residues as a source of carbon and energy. The microbiological degradation or modification of organic residuals will not only directly affect the mobility of these compounds, but may also affect the mobility of salts and trace metals through the alteration of the chemical properties of retorted shale (e.g., $\mathrm{pH}$, Eh, alteration of valence and formation of organic chelates) (Jenne 1968, Mortenson 1963, Wildung et a1. 1979). 
Situations in which environments initially free of microbial life are subsequently colonized by microorganisms, are not uncommon (Alexander 1971). In such cases initial microbial colonization is governed primarily by the physical and chemical composition of the environment (Harrison 1978). The pioneering organism or organisms wi11 proliferate to a point where either nutrients (e.g., C, N, P) become limiting or the physical and chemical composition of the environment changes to resist further growth (Alexander 1971). In environments of low nutrient value, the death of pioneering organisms will provide growth factors for newly colonizing species. Such a process will occur many times before a heterogeneous population will develop, and is best exemplified by the formation of soil by the weathering of rock and incorporation of organic matter derived from numerous microorganisms and their degradation products (Webley et al. 1963).

In this paper, we discuss the microbial colonization of retorted shale in field and laboratory studies. Primary emphas is is placed on the initial colonizing processes as well as nutrient requirements during this phase.

\section{MATERIALS AND METHODS}

Colonization of retorted shale was examined at a field site designed to represent retorted shale disposal conditions and under controlled conditions in the laboratory.

\section{Field Studies}

Lysimeter. Microbial colonization was measured with time in soil and retorted shale samples from field lysimeters constructed at the Department of Energy Rifle 0il Shale Facility, Anvil Points, Colorado. The lysimeter was constructed to model a high elevation disposal site where most of the oil shale development will occur. The lysimeter was originally designed (Harbert 1978) to yield information on a number of physical, chemical, and biological questions concerning the disposal and revegetation of retorted shale. Retorted shale, which had been obtained directly from the Paraho retort that operates in the direct heating 
mode, was placed in the lysimeter (March 21 - April 7, 1977) to give a $90 \mathrm{~cm}$ deep compacted zone $\left(1.5\right.$ to $\left.1.6 \mathrm{~g} / \mathrm{cm}^{3}\right)$ under a $150 \mathrm{~cm}$ uncompacted zone $\left(1.2\right.$ to $\left.1.4 \mathrm{~g} / \mathrm{cm}^{3}\right)$ in six treatments; i.e., retorted shale alone, retorted shale plus $20 \mathrm{~cm}, 40 \mathrm{~cm}, 60 \mathrm{~cm}$, and $80 \mathrm{~cm}$ soil overburdens and soil alone. Water was applied during placement of the compacted zone for dust control. In April 1977, the retorted shale-only treatment of the lysimeter was subjected to irrigation in four wet-dry cycles to reduce the surface $\mathrm{pH}$. Each of the four cycles consisted of hand spraying $174 \mathrm{~L}$ of water over the retorted shale treatment $(6 \times 6 \mathrm{~m})$ that was then allowed to air-dry for seven days before starting the next cycle. Previous research by Bell and Berg (1976) has shown that the pH of Paraho retorted shale could be reduced from 11 to 9 by wetting and drying the shale a minimum of four times. From June 2 to June 15, the retorting shale and $20 \mathrm{~cm}$ soil overburden treatments were leached with $77 \mathrm{~cm}$ of water. Both the wet-dry cycles and the leaching procedures were conducted to optimize conditions for revegetation. From June 28 to August 17, the entire lysimeter was irrigated at an average rate of $1.25 \mathrm{~cm}$ water per day. In subsequent years, 1978 and 1979, the lysimeter was irrigated in the summer months to supplement natural precipitation to an average level of $66 \mathrm{~cm} / \mathrm{yr}$.

Sampling. Surface samples $(0-5 \mathrm{~cm})$ from the retorted shale and the retorted shale plus $20 \mathrm{~cm}$ soil overburden treatments were obtained in June 1977, April 1978 and April 1979. Each sample was placed in a sterile glass jar and stored at $0-4^{\circ} \mathrm{C}$ for transportation back to the laboratory. Enumeration of bacterial and fungal colony forming units (cfu) was performed within 48 to $72 \mathrm{hr}$. On May 2, 1978, a $150 \mathrm{~cm}$ core $2.5 \mathrm{~cm}$ in diameter was taken from the shale-only portion of the lysimeter. The core extended from the surface to the compacted zone, which could not be penetrated with the coring device. The core was divided into $30 \mathrm{~cm}$ segments and each segment was thoroughly but rapidly mixed (aerobically) and subdivided into two portions for determination of aerobic and anaerobic bacteria. Both samples were placed in sterile glass containers, stored and shipped in the same manner as surface 
samples, except that subsamples for determination of anaerobic bacteria were maintained under a nitrogen atmosphere.

The use of plate count techniques in estimating bacteria communities in soil have been critically evaluated by numerous researchers (Butterfield 1932, Skinner 1952, Weiringa 1958, Gossling 1958, Egde11 et a1. 1960, Jensen 1962). A primary criticism concerns the inability to measure the total bacterial community in soil using a given growth medium because a given growth medium is selective for certain bacteria present. The selective medium used in the present study selects for bacteria capable of growth on the specific combination of nutrients in this medium. To facilitate the presentation and discussion of results from these studies the aerobic bacterial community selected is designated AHF (aerobic heterotrophic fraction) and the anaerobic bacteria community selected is designated AnHF (anaerobic heterotrophic fraction).

Bacterial and fungal enumeration. Bacterial and fungal cfu were determined by standard pour plate techniques (Clark 1965). A selective medium that contained $1 \mathrm{mg} \mathrm{KNO}{ }_{3}, 0.5 \mathrm{mg} \mathrm{M \textrm {SO } _ { 4 } , 5 . 6 8 \mathrm { mg } \mathrm { Na }} \mathrm{HPO}_{4}, 5.45 \mathrm{mg}$ $\mathrm{KH}_{2} \mathrm{PO}_{4}, 20 \mathrm{mg}$ glucose, $5.0 \mathrm{mg}$ casamino acids, $1 \mathrm{mg}$ yeast extract, $15 \mathrm{mg}$ Difco agar and $10 \mathrm{mg}$ fungizone per $\mathrm{ml}$, adjusted to $\mathrm{pH} 7.0$, was used for enumeration of both AHF and AnHF cfu. Littman Agar (BBL) that contained $30 \mathrm{mg} / \mathrm{ml}$ streptomycin and tetracycline was used for the enumeration of fungal cfu. Serial dilutions were prepared from retorted shale and soil suspensions in $80 \mathrm{mM}$ phosphate buffer (5 g substrate per $50 \mathrm{ml}$ buffer) and were mixed by reciprocal shaking (150 rpm) for 5 minutes. For AnHF, all transfers were conducted under flowing $\mathrm{N}_{2}$ gas. Pour plates for the determination of anaerobic bacteria were incubated in BBL Gas Pak ${ }^{\otimes}$ systems. All pour plates were incubated at $25^{\circ} \mathrm{C}$ for 14 days before enumeration and visual observation of the diversity of organisms appearing in the enumeration medium.

\section{Laboratory Studies}

Microbial colonization was measured with time in liquid cultures which contained retorted shale and were inoculated with soil. 
Retorted shale and soil. The DOE Rifle $0 i 1$ Shale Facility supplied the retorted shale which was collected directly from the retort and placed in barrels. At collection the temperature of the retorted shale was $200^{\circ}$ to $300^{\circ} \mathrm{C}$. After cooling, the retorted shale was mixed, screened through a $6.3 \mathrm{~mm}$ sieve and the fraction less than $6.3 \mathrm{~mm}$ was used. Surface soil (0 to $5 \mathrm{~cm}$ ) was obtained adjacent to the field lysimeter site used for field studies. The soil was tentatively identified from a mapping unit as an Ildefonzo-Lazaer complex (Soil Conservation Service 1979).

Retorted shale cultures. Retorted shale cultures contained $10 \mathrm{~g}$ retorted shale, $100 \mathrm{mg}$ soil as microbial inoculum, $100 \mathrm{ml}$ distilled water and additional organic and inorganic amendments. Cultures were incubated at $25^{\circ} \mathrm{C}$ with reciprocal shaking $(150 \mathrm{rpm})$ for 49 days. The $\mathrm{pH}$ of the culture was monitored throughout the study by measuring the $\mathrm{pH}$ of $1 \mathrm{ml}$ samples removed from the culture. The presence of the AHF communities was determined from $1 \mathrm{ml}$ samples removed at $0,1,3$ and 7 weeks by the pour plate technique and the selective medium used in field studies. All pour plates were incubated at $25^{\circ} \mathrm{C}$ for 14 days before enumeration and visual observation of the diversity of organisms appearing in the enumeration medium. Selected colonies from these plates were isolated for further characterization.

Identification and characterization of AHF. During the enumeration of AHF cfu, colony types that were the dominate fraction of AHF community which developed in the medium, were isolated and characterized as to growth, colony morphology, gram stain, cell shape, color, mobility, formation of soluble pigment and the effect of $\mathrm{pH}$ and salt concentration $(\mathrm{NaCl})$ on growth. Specific organisms of interest were referred to the American Type Culture Collection for identification to the genus level.

Inorganic nutrient sorption studies. Nutrient sorption on retorted shale was examined in liquid cultures which contained $10 \mathrm{~g}$ retorted shale, $100 \mathrm{ml}$ distilled water and inorganic nutrients $(0.001-1.0 \mathrm{mg}$ $\mathrm{KNO}_{3}, 0.0005-0.5 \mathrm{mg} \mathrm{MgSO}_{4}, 0.00568-5.68 \mathrm{mg} \mathrm{Na}_{2} \mathrm{HPO}_{4}$ and $0.00545-5.45 \mathrm{mg}$ $\mathrm{KH}_{2} \mathrm{PO}_{4}$ per $\mathrm{ml}$ ). The culture was incubated at $25^{\circ} \mathrm{C}$ with reciprocal shaking at $150 \mathrm{rpm}$. Samples of $10 \mathrm{ml}$ were removed at $0,1,3,6$ and 
$96 \mathrm{hr}$, filtered through a $0.45 \mu$ membrane and the filtrate analyzed for nitrate, phosphate, sulfate and thiosulfate. Anion analyses were performed with a Dionex Model 10 Ion Chromatograph. The chromatograph was equipped with an anion pre-column ( $3 \times 150 \mathrm{~mm})$, an anion "brine" column ( $L-20,3 \times 50 \mathrm{~mm})$ and an anion suppressor column (6x250 mm). Samples were eluted from the columns with $3 \mathrm{mM} \mathrm{NaHCO}{ }_{3}$ plus $2.4 \mathrm{mM} \mathrm{Na}_{2} \mathrm{CO}_{3}$ followed by $9 \mathrm{mM} \mathrm{NaHCO} 3$ plus $0.0072 \mathrm{mM} \mathrm{Na}_{2} \mathrm{CO}_{3}$ at a flow rate of 150 $\mathrm{ml} / \mathrm{hr}$.

\section{RESULTS}

Field Studies

Aerobic heterotrophic bacteria and fungi in surface soil and retorted shale. Surface retorted shale and soil samples obtained from the field lysimeter over a two year period were examined for AHF cfu. Surface samples obtained in April 1978 and April 1979 were examined for fungal cfu. The total fungal and AHF cfu were not markedly different between the retorted shale and soil at all sampling times (Table 1). However, the composition of the AHF community measured in retorted shale (June 1977) was significantly different from the AHF community measured in spil (June 1977) and retorted shale and soil from later sampling periods. A single bacterium having a characteristic red pigmentation constituted $30 \%$ of the observed AHF in retorted shale sampled in June 1977. By comparison of colony morphology, pigmentation and growth characteristics on the selective medium, the organism appeared identical to organisms subsequently isolated from laboratory cultures which have been identified as members of the genus Micrococcus. This bacterium was not present in measurable number $(<1.0 \%)$ in the June 1977 soil or in retorted shale or soil obtained at later dates. In addition, the AHF communities of these samples were not dominated by a single organism.

Aerobic and anaerobic heterotrophic bacteria and fungi with depth in the retorted shale only treatment of the lysimeter. In May 1978, a core sample was obtained from the field lysimeter to measure the AHF, 
Table 1. Total heterotrophic bacterial and fungal cfu in retorted shale and soil from field studies.

Sample $\quad$ Retorted Shale ${ }^{(a)} \quad$ Soil ${ }^{(b)}$

\section{Bacterial cfu}

$\begin{array}{lll}\text { June } 1977 & 2.0,2.5 \times 10^{6} & 2.2,1.9 \times 10^{6} \\ \text { Apri1 } 1978 & 1.0,1.0 \times 10^{7} & 0.96,1.1 \times 10^{7} \\ \text { Apri1 } 1979 & 1.8,1.9 \times 10^{7} & 1.2,1.2 \times 10^{7}\end{array}$

\section{Fungal cfu}

April 1978

$4.5,5.5 \times 10^{4}$

$4.5,5.1 \times 10^{4}$

April 1979

$1.2,1.1 \times 10^{4}$

$5.7,6.6 \times 10^{4}$

(a) Values represent replicate determinations (cfu per g dry retorted shale). (b) Values represent replicate determinations (cfu per g dry soil). 
AnHF and fungal cfu with depth in the field lysimeter. As shown in Table 2, the highest fungal cfu/g dry wt occurred at the 0 to $30 \mathrm{~cm}$ level and decreased to less than 100 fungal cfu/g dry wt at the deepest level. The AHF and AnHF cfu decreased from the 0 to $30 \mathrm{~cm}$ level to the 90 to $120 \mathrm{~cm}$ level. However, a sharp increase was observed for both bacterial types at the 120 to $150 \mathrm{~cm}$ level. The highest ratio $(\sim 1: 4.5)$ of AnHF to AHF cfu was observed at the 120 to $150 \mathrm{~cm}$ level just above the compacted zone which was water saturated (Garland et al. 1979). These results would suggest that at or near the compacted zone anaerobic conditions are developing that contribute to the growth of anaerobic bacteria.

\section{Laboratory Studies}

Effect of inorganic nutrients on colonization of retorted shale. In laboratory studies, AHF communities developed in retorted shale cultures that contained retorted shale as sole source of carbon, soil as the bacterial inoculum and inorganic salt amendments. Both the time required for initiation of observable growth and the composition of the AHF community were dependent on which inorganic salts were added as amendments (Table 3 ). When the inorganic salts amendment consisted of phosphate plus $\mathrm{KNO}_{3}$ and $\mathrm{MgSO}_{4}$ or phosphate alone, AHF growth was observed within seven days of incubation. In contrast, when either no amendments, $\mathrm{KNO}_{3}$ or $\mathrm{MgSO}_{4}$ were added to cultures, AHF growth was not observed until after seven days (no amendment) or after three weeks $\left(\mathrm{KNO}_{3}\right.$ and $\left.\mathrm{MgSO}_{4}\right)$ and, in addition, the AHF cfu was considerably reduced relative to cultures amended with phosphate plus $\mathrm{KNO}_{3}$ and $\mathrm{MgSO}_{4}$ or phosphate alone (Table 3 ). The AHF community that developed in retorted shale cultures amended with phosphate plus $\mathrm{KNO}_{3}$ and $\mathrm{MgSO}_{4}$ or phosphate alone was composed entirely of Micrococcus species (Table 3 ) having characteristics similar to those observed in field studies. The AHF community appearing in the culture amended with $\mathrm{KNO}_{3}$ was dominated (67\%) by Micrococcus species whereas the AHF communities appearing in cultures prepared with no amendments or $\mathrm{MgSO}_{4}$ were heterogeneous and did not contain detectable $(<1.0 \%)$ Micrococcus species. 
Table 2. Distribution of heterotrophic bacteria, anauskic bacteria and fungi with depth in the retorted shale lysimeter.

\begin{tabular}{|c|c|c|c|}
\hline \multicolumn{4}{|c|}{ Bacterial cfu ${ }^{(a)}$} \\
\hline Depth $(\mathrm{cm})$ & $\underline{\mathrm{AHF}}$ & $\underline{A n H F}$ & Fungal cfu \\
\hline $0-30$ & $\begin{array}{l}1.2 \\
1.1\end{array} \times 10^{6}$ & $1.9 \times 10^{4}$ & $\begin{array}{l}4.6 \\
5.2 \times 10^{4}\end{array}$ \\
\hline $30-60$ & $\begin{array}{l}2.8 \\
3.1\end{array} \times 10^{5}$ & $\begin{array}{l}7.3 \\
6.0 \times 10^{3}\end{array}$ & $\begin{array}{l}8.0 \\
8.2\end{array}$ \\
\hline $60-90$ & $1.3 \times 10^{4}$ & $<10^{2}$ & $\begin{array}{l}2.8 \\
4.4\end{array} \times 10^{2}$ \\
\hline $90-120$ & $\begin{array}{l}3.7 \\
3.8\end{array} \times 10^{3}$ & $<10^{2}$ & $<10^{2}$ \\
\hline $120-150$ & $9.9 \times 10^{5}$ & $\begin{array}{l}2.1 \\
2.0 \times 10^{5}\end{array}$ & $<10^{2}$ \\
\hline
\end{tabular}

(a) Values represent replicate determinations.

(b) Pour plates could not be enumerated. 
Table 3. Growth of bacteria on retorted shale as sole carbon source in liquid media containing mineral salts

\begin{tabular}{|c|c|c|c|}
\hline $\begin{array}{l}\text { Mineral Salts } \\
\text { Composition }\end{array}$ & $\begin{array}{l}\text { Time } \\
\text { (wks) }\end{array}$ & $\begin{array}{l}\log _{10} \\
\text { Bacterial cfu }\end{array}$ & $\%$ Micrococcus \\
\hline Phosphate $(a)$ & 0 & $<2,<2$ &.$-(c)$ \\
\hline $\mathrm{KNO}_{3}$ & 1 & $6.25,6.39$ & 99,98 \\
\hline \multirow[t]{2}{*}{$\mathrm{MgSO}_{4}$} & 3 & $6.88,6.97$ & 100,100 \\
\hline & 7 & $6.93,6.90$ & 100,100 \\
\hline \multirow[t]{4}{*}{ Phosphate } & 0 & $<2,<2$ & -- \\
\hline & 1 & $5.46,5.53$ & 100,100 \\
\hline & 3 & $6.81,6.86$ & 100,100 \\
\hline & 7 & $7.01,7.08$ & 100,100 \\
\hline \multirow[t]{4}{*}{$\mathrm{KNO}_{3}$} & 0 & $<2,<2$ & -- \\
\hline & 1 & $<2,<2$ & -- \\
\hline & 3 & $<2,<2$ & -- \\
\hline & 7 & $4.81,4.79$ & 69,63 \\
\hline \multirow[t]{4}{*}{$\mathrm{MgSO}_{4}$} & 0 & $<2,<2$ & -- \\
\hline & 1 & $<2,<2$ & -- \\
\hline & 3 & $<2,<2$ & -- \\
\hline & 7 & $4.64,4.77$ & $<1,<1$ \\
\hline \multirow[t]{4}{*}{$\mathrm{H}_{2} \mathrm{O}$} & 0 & $<2,<2$ & -- \\
\hline & 1 & $<2,<2$ & -- \\
\hline & 3 & $3.86,3.92$ & $<1,<1$ \\
\hline & 7 & $5.18,5.18$ & $<1,<1$ \\
\hline
\end{tabular}

(a) The concentration of mineral salts was: phosphate $(80 \mathrm{mM}), \mathrm{KNO}_{3}(1 \mathrm{mg} / \mathrm{ml})$ and $\mathrm{MgSO}_{4}(0.5 \mathrm{mg} / \mathrm{ml})$.

(b) Values represent replicate determinations.

(c) Bacterial cfu was less than detectable, therefore, percent Micrococcus could not be evaluated. 
Identification of Micrococcus species. Sixteen bacterial colonies representing the dominant colony type were isolated from enumeration plates obtained from colonization studies. All isolates were grampositive, coccoid in shape, non-motile, formed a diffusable pigment on the selective medium, formed a non-diffusable yellow-orange to salmonpink pigment and did not appear in the selective media until the seventh day of incubation. Of the sixteen isolates, eight demonstrated near maximal growth rates up to $\mathrm{pH} 9.0$ and the remaining eight showed similar results up to $\mathrm{pH} 10.0$, eleven demonstrated near maximal growth rates up to $5 \% \mathrm{NaCl}$, four up to $2.5 \%$ and a single organism was strongly affected by salt and grew at only $0.5 \% \mathrm{NaCl}$ or less. An organism representing the mid range of the above characteristics of this collection was identified by the American Type Culture Collection to be of the genus Micrococcus.

Effect of phosphate concentration. The effect of added phosphate to enhance the growth of Micrococcus species in retorted shale cultures was concentration-dependent (Table 4). With phosphate concentrations of 8 and $80 \mathrm{mM}$, AHF growth was detected by the first sampling period (7 days). The AHF community that appeared was composed entirely of Micrococcus species. With phosphate concentrations of $0.8 \mathrm{mM}$ or less, AHF cfu were not detected until after three weeks of incubation. At these lower concentrations the composition of the AHF community was heterogenous and did not contain detectable levels $(<1.0 \%)$ of Micrococcus species.

Sorption of inorganic nutrients to retorted shale. The concentration-dependence of phosphate in enhancing the growth of Micrococcus species in retorted shale cultures (Table 4) may be attributed to the rapid insolubilization of added phosphate by either sorption to retorted shale or precipitation of calcium phosphate. In this regard, a study was conducted to determine the soluble concentration of phosphate and other inorganic salts amendments (Table 5 ) in retorted shale cultures. 
Table 4. Phosphate requirements for growth of microorganisms on retorted shale as the sole source of carbon

\begin{tabular}{|c|c|c|c|}
\hline $\begin{array}{l}\text { Concentration } \\
\text { of Phosphate } \\
\quad(\mathrm{mM})\end{array}$ & $\begin{array}{l}\text { Time } \\
\text { (wks) }\end{array}$ & $\begin{array}{l}\log _{10} \\
\text { Bacterial cfu } \\
(a)\end{array}$ & $\%$ Micrococcus \\
\hline \multirow[t]{4}{*}{80} & 0 & $<2,<2$ & $\ldots$ (b) \\
\hline & 1 & $6.43,6.64$ & 100,100 \\
\hline & 3 & $6.69,6.79$ & 100,100 \\
\hline & 7 & $6.61,6.52$ & 100,100 \\
\hline \multirow[t]{4}{*}{8} & 0 & $<2,<2$ & - \\
\hline & 1 & $6.76,6.68$ & 100,100 \\
\hline & 3 & $6.77,6.86$ & 100,100 \\
\hline & 7 & $6.48,6.53$ & 100,100 \\
\hline \multirow[t]{4}{*}{0.8} & 0 & $<2,<2$ & -- \\
\hline & 1 & $<2,<2$ & -- \\
\hline & 3 & $<2,<2$ & -- \\
\hline & 7 & $4.85,4.90$ & 0,0 \\
\hline \multirow[t]{4}{*}{0.08} & 0 & $<2,<2$ & -- \\
\hline & 1 & $<2,<2$ & - \\
\hline & 3 & $<2,<2$ & -- \\
\hline & 7 & $5.58,5.65$ & 0,0 \\
\hline \multirow[t]{4}{*}{0} & 0 & $<2,<2$ & -- \\
\hline & 1 & $<2,<2$ & -- \\
\hline & 3 & $<2,<2$ & -- \\
\hline & 7 & $5.49,5.80$ & 0,0 \\
\hline
\end{tabular}

(a) Values represent replicate determinations.

(b)Bacterial cfu was less than detectable, therefore percent Micrococcus could not be evaluated. 
Table 5. Time dependence of soluble anion concentration in liquid cultures.

\begin{tabular}{|c|c|c|c|c|c|}
\hline \multirow[b]{2}{*}{$\begin{array}{l}\text { Concentration } \\
\text { Mineral Salts }\end{array}$} & \multirow[b]{2}{*}{$\begin{array}{l}\text { Time } \\
(h r)\end{array}$} & \multicolumn{4}{|c|}{ Anion (ppm) } \\
\hline & & $\mathrm{S}_{2} \mathrm{O}_{3}{ }^{2-}$ & $\mathrm{NO}_{3}^{-}$ & $\mathrm{SO}_{4}{ }^{2-}$ & $\mathrm{PO}_{4}^{3-}$ \\
\hline \multirow[t]{5}{*}{ Complete $^{(\mathrm{a})}$} & 0 & $\ldots(b)$ & 630 & 350 & 10,600 \\
\hline & 1 & $<4$ & 570 & 410 & 8,800 \\
\hline & 3 & $<4$ & 540 & 540 & 7,700 \\
\hline & 6 & $<4$ & 520 & 560 & 6,600 \\
\hline & 96 & 210 & 440 & 810 & 410 \\
\hline \multirow[t]{5}{*}{$1 / 10$ di 1} & 0 & -- & 42 & 33 & 720 \\
\hline & 1 & 11 & 60 & 280 & 360 \\
\hline & 3 & 18 & 58 & 320 & 140 \\
\hline & 6 & 26 & 56 & 370 & 36 \\
\hline & 96 & 260 & 35 & 380 & $<0.1$ \\
\hline \multirow[t]{5}{*}{ 1/100 dil. } & 0 & -- & 4.3 & 2.6 & 76 \\
\hline & 1 & 47 & 4.4 & 200 & 0.2 \\
\hline & 3 & 30 & 4.0 & 230 & $<0.1$ \\
\hline & 6 & 46 & 4.4 & 260 & $<0.1$ \\
\hline & 96 & 330 & 3.0 & 350 & $<0.1$ \\
\hline \multirow[t]{5}{*}{$1 / 1000$ di 1} & 0 & -- & 0.36 & 24 & 6.0 \\
\hline & 1 & 17 & 0.63 & 240 & $<1.0$ \\
\hline & 3 & 28 & 0.63 & 290 & $<0.1$ \\
\hline & 6 & 40 & 0.63 & 310 & $<0.1$ \\
\hline & 96 & 210 & 1.74 & 330 & $<0.1$ \\
\hline
\end{tabular}

(a) The undiluted salt solution contained: phosphate $(80 \mathrm{mM}), \mathrm{KNO}_{3}(1 \mathrm{mg} / \mathrm{ml})$, and $\mathrm{MgSO}_{4}(0.5 \mathrm{mg} / \mathrm{ml})$.

(b) Data was not obtained. 
At the lower concentrations of phosphate $(0.8$ and $0.08 \mathrm{mM})$ where no Micrococcus species were detected in retorted shale cultures, essentially all of the phosphate was lost from solution within the first hour of incubation. In contrast, at the higher concentration of phosphate where Micrococcus species dominated the AHF community, significant levels of phosphate were soluble after six hours ( $8 \mathrm{mM}$ ) and four days $(80 \mathrm{mM})$. Apparently, the phosphate lost from solution at the lower concentrations was unavailable for the growth of Micrococcus species.

In sharp contrast to phosphate, sulfate and nitrate were not rapidly lost from solution (Table 5). In fact, at the three lowest concentrations of added salts amendments, the sulfate added was far less than the sulfate solubilized from the retorted shale. Nitrate showed a slight decrease in concentration during incubation except at the lowest concentration where a 4-fold increase was observed. Thus, sulfate and nitrate do not appear to be limiting or to have an effect on the growth of Micrococcus species in retorted shale cultures.

$\mathrm{pH}$ profile of retorted shale liquid cultures. All retorted shale cultures, with few exceptions, demonstrated a similar pH profile over the incubation period. The $\mathrm{pH}$ of cultures rose rapidly within the first 2-3 days to a value of 9.1 to 11.6 (Figure 1). Within the next 7 or 8 days, the $\mathrm{pH}$ dropped to a level of 9.4 to 10.0. After 49 days, they had decreased to a level of 8.9 to 9.5 .

The decrease in pH likely occurs from the chemical oxidation of reduced sulfur to sulfate and, to some extent, from recarbonization by atmosphere or microbiologically-produced carbon dioxide. The role of reduced sulfur species is amply demonstrated by the increase in thiosulfate observed in sorption studies (Table 5 ). Thiosulfate is thought to be an intermediate in the chemical oxidation of reduced sulfur species (Pourbaix 1966). Similar increases in thiosulfate have been observed in laboratory column and field lysimeter studies of the leaching of retorted shale. 
Effect of organic nutrients on colonization of retorted shale amended with phosphate. The effect of organic nutrients on the growth of the AHF community in retorted shale cultures containing phosphate was dependent on the concentration of added nutrients (Table 6). When several levels of a complex nutrient mixture (casamino acids, yeast extract and glucose) were amended to retorted shale cultures containing $80 \mathrm{mM}$ phosphate, AHF communities were detected in all cultures when examined after seven days of incubation. However, the total AHF cfu observed at seven days and over the entire seven weeks of incubation decreased with decreasing levels of added nutrients by approximately two orders of magnitude. Major differences were also observed in the composition of AHF community. At the highest level of added nutrients the composition of the AHF community detected was heterogeneous in nature. In contrast, only Micrococcus species were detected in cultures amended at the lower levels of organic nutrients and in the control, which contained phosphate alone.

The highest level of amended organic nutrients appeared to contribute to the rapid growth of a more diverse group of AHF bacteria in the retorted shale culture. However, at this level of organic nutrients, the initial $\mathrm{pH}$ of the retorted shale culture was reduced in comparison to that found for lower levels of organic nutrients, as well as cultures from other experiments, but did increase to the level observed in other experiments after 4 days incubation (Figure 1). In this regard, the development of a heterogeneous AHF community in this case may also be associated with the initial low $\mathrm{pH}$ values.

\section{DISCUSSION}

The limitations of determining bacterial or fungal cfu that are representative of microbial communities by plate counts have been examined by numerous researchers (Butterfield 1932, Egdell et al. 1960, Gossling 1958, Jensen 1962, Skinner et al. 1952, Weiringa 1958); the general consensus is that plate counts are by no means quantitative for the total microbial community and only represent a fraction of the total. Moreover, this fraction also does not represent an absolute 
Table 6. Effect of complex organic substrates on the growth of microorganisms on retorted shale.

\begin{tabular}{|c|c|c|c|}
\hline $\begin{array}{c}\text { Concentration } \\
\text { Organics }\end{array}$ & $\begin{array}{r}\text { Time } \\
(\mathrm{d})\end{array}$ & ${ }_{\text {Bacterial cfu }}^{\log _{10}}$ & $\%$ Micrococcus \\
\hline \multirow[t]{4}{*}{ Complete $^{(a)}$} & 0 & $<2,<2$ &.$-(c)$ \\
\hline & 1 & $8.40,8.36$ & $<1,<1$ \\
\hline & 3 & $8.46,8.56$ & $<1,<1$ \\
\hline & 7 & $8.38,8.32$ & $<1,<1$ \\
\hline \multirow[t]{4}{*}{$1 / 10 \mathrm{dil}$} & 0 & $<2,<2$ & - \\
\hline & 1 & $6.90,6.93$ & 100,100 \\
\hline & 3 & $7.20,7.26$ & 85,81 \\
\hline & 7 & $6.95,6.95$ & 97,98 \\
\hline \multirow[t]{4}{*}{$1 / 100 \mathrm{dil}$} & 0 & $<2,<2$ & -- \\
\hline & 1 & $6.61,6.66$ & 100,100 \\
\hline & 3 & $6.00,6.00$ & 86,85 \\
\hline & 7 & & \\
\hline No organic & 0 & $<2,<2(d)$ & -- \\
\hline \multirow[t]{3}{*}{ amendment } & 1 & $5.15,--$ & $99,--(d)$ \\
\hline & 3 & $6.51,6.56$ & 100,97 \\
\hline & 7 & $6.62,6.66$ & 100,100 \\
\hline
\end{tabular}

(a) The undiluted complex organic solution contained: glucose $(2 \mathrm{mg} / \mathrm{ml})$, yeast extract $(1 \mathrm{mg} / \mathrm{ml})$ and casamino acids $(5 \mathrm{mg} / \mathrm{ml})$.

(b) Values represent replicate determinations.

(c) Bacterial cfu was less than detectable, therefore, percent

Micrococcus could not be evaluated.

(d) Pour plates could not be enumerated. 


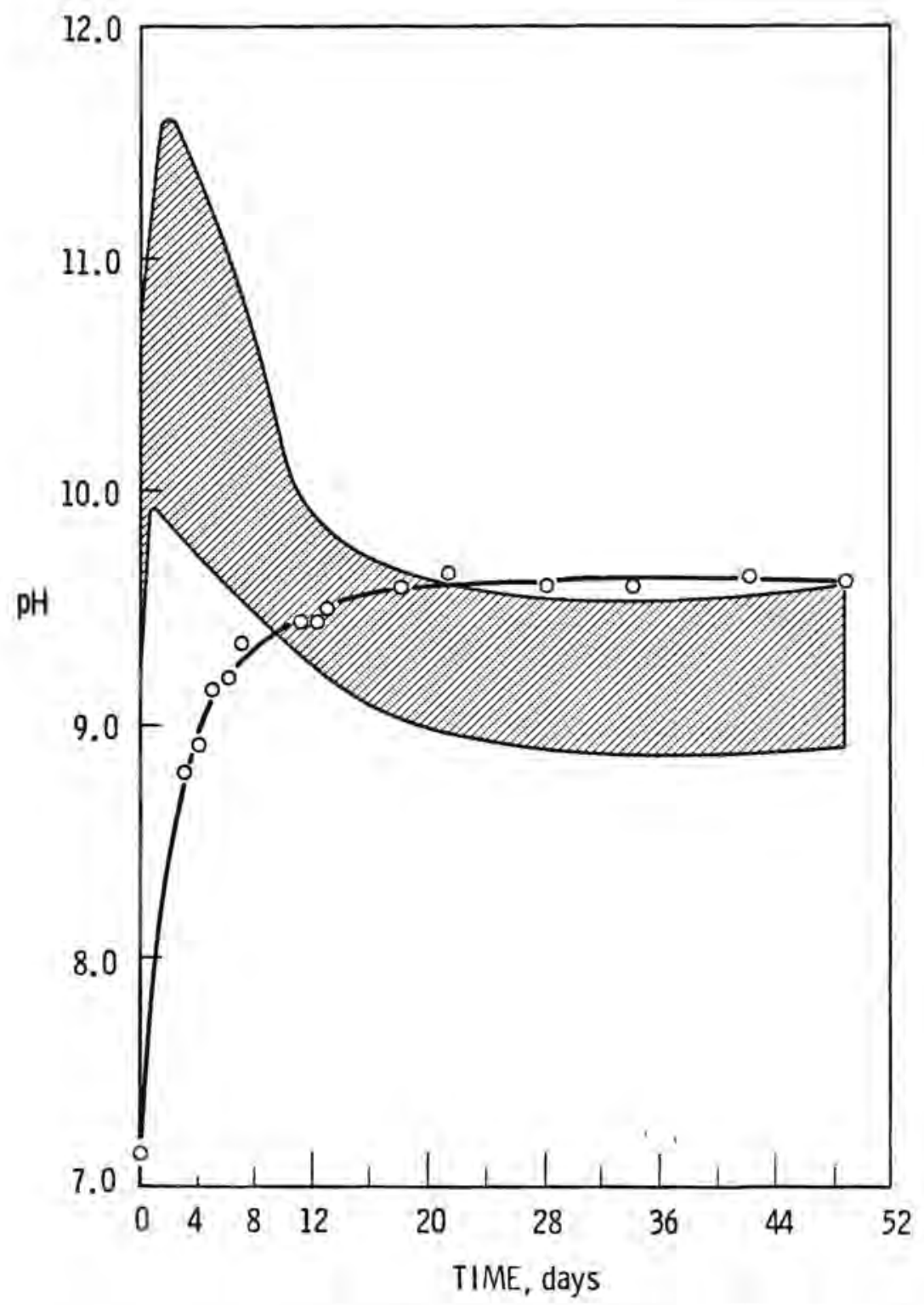

Figure 1. $\mathrm{pH}$ of liquid retorted shale cultures with time of incubation. The shaded area represents the range within which most retorted shale cultures fell. The line with the open circles represents the $\mathrm{pH}$ profile for the culture which contained the highest organic nurtient amendment. 
value but a relative value dependent on well controlled and reproducible laboratory techniques, as well as the composition of the plating media. Media derived from natural materials, i.e., soil, tend to vary from batch to batch causing variable counts of the indigenous organisms whereas enriched or commercially prepared media, though more reproducible, tends to select for a smaller fraction of the indigenous organisms. Despite these objections, plate counting can be useful in detecting numerical and community compositional differences within a given set of experiments where relative observation is the controlling factor. Only those organisms able to grow on the selective medium of choice and within the limits of the plating technique can be observed and evaluated in such studies.

To maintain reproducibility between both field and laboratory studies, a selective plating media composed of commercially available nutrients has been used. These studies show that soil microorganisms are capable of colonizing retorted shale using it as the sole source of carbon and energy. Initially the select bacterial community examined in irrigated disposed retorted shale was dominated by Micrococcus species. The rate of colonization, as well as the composition of this AHF community, appears to be dependent on the nutrient status of the retorted shale in laboratory studies. The addition of phosphate ( $>8 \mathrm{mM})$ as a phosphorous source to laboratory cultures stimulated the rate of colonization but led to a AHF community composed of the single genus Micrococcus. At concentrations less than $8 \mathrm{mM}$, phosphate did not produce a similar effect presumably because of rapid precipitation of calcium phosphate or sorption of the phosphate to the retorted shale, reducing its availability. Apparently the addition of phosphate to retorted shale cultures stimilates a rapid colonization by Micrococcus species in defference to other AHF species. In the absence of phosphate, the growth of Micrococcus species may be markedly reduced or they lack the ability to compete for available nutrients with other AHF species. Either, or both, possibilities might account for their absence from such cultures. 
The addition of a sulfur or nitrogen source $\left(\mathrm{MgSO}_{4}\right.$ or $\left.\mathrm{KNO}_{3}\right)$ to retorted shale cultures did not appreciably alter colonization by AHF communities, i.e., neither the selective colonization affected by phosphate or the retarded colonization observed in the absence of amendments was altered by the addition of $\mathrm{MgSO}_{4}$ or $\mathrm{KNO}_{3}$. The absence of a sulfur requirement is due to the ready solubility of sulfate associated with the retorted shale cultures. Sulfate has also been found to be the major anion in leachates from field lysimeters (Garland et al. 1979). Nitrate, however, was not detectable in leachates from field lysimeters in the first year (unpublished data) and was markedly lower in solubility in retorted shale cultures than sulfate. Either this low level of nitrate is sufficient, or other forms of nitrogen, possibly organic $\mathrm{N}$ or ammonia, are present and available for microbial growth. Ammonia, however, seems less likely because of the high $\mathrm{pH}$ of the cultures.

In the presence of phosphate the selective advantage for the growth of Micrococcus species in retorted shale cultures appears to be very strong. Only when a high level of a complex mixture of carbon substrates capable of supporting the growth of a wide variety of bacteria (Figure 1) was amended in presence of phosphate was rapid colonization observed for a heterogenous AHF community. It is of interest that of the 16 Micrococcus isolates obtained, half grew well up to pH 9.0 and the remainder grew well up to $\mathrm{pH}$ 10.0, suggesting that one selective advantage may be their ability to grow at high pH. Other selective pressures are also suggested. When liquid cultures of the selective medium for AHF, which also contained phosphate, was adjusted to $\mathrm{pH} 10.0$, inoculated with soil incubated for 24 to 48 hours, and enumerated with selective medium adjusted to $\mathrm{pH} \mathrm{7.0,} \mathrm{a} \mathrm{heterogenous} \mathrm{mixture} \mathrm{of} \mathrm{AHF} \mathrm{was}$ observed. No Micrococcus species were found. These results indicate that a number of AHF bacteria in the soil used in these studies are capable of growth at high $\mathrm{pH}$; however, only Micrococcus species appeared in retorted shale cultures containing phosphate. Whatever these selective pressures may be, the early dominance in the field and in retorted shale cultures of a single genus of AHF, Micrococcus, would 
indicate that initially the retorted shale represents a stressed environment for microorganisms. In field studies, this appears to be a transitional state in a microbial succession that leads to a heterogenous community with time, depending on changes in the physicochemical properties of the retorted shale that occur on mineral weathering and the addition of organic nutrients through the turnover of microorganisms present in the early stages of microbial colonization.

As exemplified by the laboratory studies, the rate, as well as the composition of the microbial community that develops, will depend on the types of organic and inorganic amendments added to the retorted shale. Similar effects should also be observed in the field. In field situations similar to those expected for the commercial disposal sites of retorted shale, nutrient amendments may occur by the addition of retort or other water for dust control or irrigation (Crawford et a1. 1977) and the use of fertilizers or mulchs in revegetation of these sites. The effect of added phosphate was demonstrated in field studies where dominance of the AHF community by Micrococcus species in initial retorted shale samples can, in part, be attributed to phosphate present in irrigation waters.

Because of the large quantities of retorted shale that will be produced by commercial scale above-ground retorts and the terrain in parts of the western oil shale region, retorted shale disposal piles may be hundreds of meters in depth (Crawford et al. 1977). These studies indicate that if diffusion of oxygen is limited and/or if percolation of water is sufficient, subsurface levels of the pile may become anaerobic, resulting in the development of microbial communities, in particular, anaerobic bacteria capable of growth under such conditions. Consideration must, therefore, be given to the effects of anaerobic conditions and the corresponding activities of facultative and obligate anaerobic microorganisms on the solubility and chemical form of inorganic and organic residuals. Because of the proposed depths of retorted shale disposal sites, the effects of anaerobic bacteria may be paramount. Unlike soil profiles where organic content decreases with depth with a corresponding decrease in the size of the microbial 
community, the organic content of retorted shale piles will essentially be uniform throughout, thus suggesting a similar distribution of anaerobic bacteria. In this regard, and depending on the moisture content with depth, anaerobic bacteria may be the major source of biological effects within retorted shale disposal sites.

The effects of microorganisms on the safe disposal of retorted shale will be many-fold involving both negative and positive aspects. Continued study of microbial processes associated with disposed retorted shale will be required to effect proper management of this oil shale waste. 


\section{REFERENCES}

Alexander, M. 1971. Microbial Ecology, John Wiley and Sons, Inc., New York.

Butterfield, C. T. 1932. The selection of a dilution water for bacteriological examination. J. Bacterial. 23:355-368.

Clark, F. E. 1965. Agar-plate method for total microbial count, p. 1460-1466. In C. A. Block (ed.). Methods of soil analysis, part 2, chemical and microbiological properties. American Society of Agronomy, Inc., Madison, WI.

Crawford, K. W., C. H. Prien, L. B. Baboolal, C. C. Shih, and A. A. Lee. 1977. A preliminary assessment of the environmental impacts from 011 shale developments. EPA-600/7-77-069.

Development Engineering, Inc., and Woodward-Clyde Consultants. 1979. Disposal of retorted oil shale from the Paraho oil shale project. U.S. Bureau of Mines, Report No. OFR 27-77.

Egde11, J. W., W. A. Cuthbert, C. A. Searlett, and S. B. Thomas. 1960. Some studies of the colony count technique for soil bacteria. J. Appl. Bact. 23:69-86.

Garland, T. R., R. E. Wildung, and H. P. Harbert. 1979. Influence of irrigation and weathering reactions on the composition of percolates and retorted oil shale in field lysimeter, p. 52-57. In J. H. Ganz (ed.) Twelfth oil shale symposium proceedings. Colorado School of Mines Press, Boulder, c0.

Gossling, B. S. 1958. The loss of viability of bacteria in suspension due to changing the ionic environment. J. Appl. Bact. 21:220-243.

Harbert III, H. P. 1978. Vegetative stabilization of Paraho spent oil shales, lysimeter study. Thesis, Colorado State University, Fort Collins, co.

Harrison, Jr., A. P. 1978. Microbial succession and mineral leaching in an artificial coal spoil. Appl. and Environ. Microbiol. 36:861-869.

Jenne, E. A. 1968. Controls on $\mathrm{Mn}, \mathrm{Fe}, \mathrm{Co}, \mathrm{Ni}, \mathrm{Cu}, \mathrm{Zn}$ concentrations in soil and water: the significant role of hydrous $\mathrm{Mn}$ and Fe oxides. Adv. in Chem. Ser. 73:337-387.

Jensen, V. 1962. Studies on the microflora of Danish beach forest soils I. The dilution plate count technique for the enumeration of bacteria and fungi in soil. Zentbl. Bakt. Parasitkde Abt. II. 116:13-32. 
Mortenson, J. L. 1963. Complexing of metals by soil organic matter. Soil Sci. Soc. Proc. 27:197-186.

Pourbaix, M. 1966. Atlas of electrochemical equilibrium in aqueous solutions. Permagon Press, Ltd., New York, NY.

Routson, R. C., R. E. Wildung, and R. M. Bean. 1979. A review of the environmental impact of ground disposal of $0 i 1$ shale wastes. $J$. Environ. Qua1. 8:14-19.

Skinner, F. A., P. C. T. Jones, and J. E. Mollison. 1952. A comparison of a direct and a plate-counting technique for the quantitative estimation of soil microorganisms. J. Gen. Microbiol. 6:261-271.

Soil Conservation Service. 1979. Preliminary soil survey of Garfield County, CO.

Webley, D. M., M. E. K. Henderson, and I. F. Taylor. 1963. The microbiology of rocks and weathered stones. J. Soil Sci. 4: $102-112$.

Weiringa, K. T. 1958. The problems of standardization of methods in use in microbiological soil research. Neth. J. Agric. Sci 6:61-67.

Wildung, R. E., T. R. Garland, and H. Drucker. 1979. Nickel complexes with soil microbial metabolites - mobility and speciation in soils, $p$. 181-200. In E. A. Jenne (ed.). Chemical Modeling in Aqueous Systems. American Chemical Society, Washington. 


\section{DISTRIBUTION}

No. of

Copies

OFFSITE

27 DOE Technical Information Center

R. Merril Coomes

TOSCO Corporation

10100 Santa Monica Blvd.

Los Angeles, CA 90067

J. Phyllis Fox

J. Phyll is Fox Consulting Serv.

1988 Calịfornia

Berkeley, CA 94703

Ralph E. Franklin

U.S. Department of Energy

ER-75 GTN

Washington, DC 20545

James Godlove

White River Shale 0il Corp.

115 South Main Street

Suite 500 Prudential Bldg.

Salt Lake City, UT 84111

Lawrence B. Gratt

IWG Corp.

975 Hornblend Street

Suite C

San Diego, CA 92109

Robert N. Heistand

Anvil Points, Box A

Rifle, C0 81650

Jane King

American Petroleum Institute

2101 L Street, N.W.

Washington, DC 20037

Donald A. Klein

Colorado State University

Dept. of Microbiology

Fort Collins, CO 80524
No. of

Copies

OFFSITE

Helen M. McCammon

Ecological Research Division

$\mathrm{EV}-34$

E-201 GTN

Office of Energy Research

Washington, DC 20545

Dennis Miller

National Research Council

2101 Constitution Ave., N.W. Room JH 734

Washington, DC 20418

Glenn Miller

Area $0 i l$ Shale Supervisor's

Office

131 North 6th Street

Suite 300

Grand Junction, CO 81501

Kathy Petersen

Center for Environ. Sciences

University of Colorado

1100 14th Street

Campus Box 136

Denver, CO 80202

Edward Redente

Colorado State University

Department of Range Sciences

Ft. Collins, CO 80523

Carlton B. Scott

Union $0 i 1$ Company

461 S. Boylston Street

Los Angeles, CA 90017

Dave Shelton, Director

Colorado Mined Land

Reclamation

1313 Sherman Street

Room 423

Denver, CO 80203 
No. of

Copies

\section{OFFSITE}

G. C. Slawson

Rio Blanco 0il Shale Company

2851 South Parker Road

Suite 500

Aurora, CO 80014

Allen Verstuyft

Chevron Shale 0il Company

Great West Plaza, Tower 2

1625 Broadway

Suite 2150

Denver, CO 80202

Jim Westhoff

Laramie Energy Technical Center

University Station

P.0. Box 3395

Laramie, WY 82071

ONSITE

DOE Richland Operations Office

H. E. Ransom

Marine Research Laboratory (Sequim)

R. L. Schmidt

36 Pacific Northwest Laboratory

K.E. Byers (4) J.E. Rogers (10)

A.R. Felmy N.M. Sherer

J.S. Fruchter W.L. Templeton

T.R. Garland R.E. Wildung

D.C. Girvin W.R. Wiley

A.J. Haverfield B.E. Vaughan

E.A. Jenne J.M. Zachara

K.M. Krupka Technical

D.E. Olesen

R.G. Riley Information (5)

Publishing

Coordination (2) 